\title{
PENCATATAN PERKAWINAN DALAM KONSEP NEGARA HUKUM PANCASILA
}

\author{
Liky Faizal \\ Dosen Fakultas Syariah UIN Raden Intan Lampung \\ J1. Endro Suratmin Sukarame Bandar Lampung \\ Email: likyfaisal@,radenintan.ac.id
}

\begin{abstract}
Abstark: Negara hukum Pancasila memiliki merupakan konsep negara hukum yaitu didasarkan pada tiga pilar pengakuan dan perlindungan hak asasi manusia, peradilan yang bebas dan tidak memihak, dan asas legalitas dalam arti formal maupun material, dan di lain pihak, diwarnai oleh aspirasi-aspirasi keIndonesiaan yaitu lima nilai fundamental dari Pancasila yang dirumuskan secara materiil didasarkan pada cara pandang bangsa Indonesia dalam bernegara yang bersifat integralistik khas Indonesia. Banyaknya interpretasi hukum secara jelas telah ditampilkan dalam teks undangundang, dalam hal ini mengenai persoalan pencatatan perkawinan baik di dalam UU No. 1 Tahun 1974 dalam pasal 2 ayat (1) dan (2) maupun dalam KHI pasal 4, 5, 6 dan 7 yang secara eksplisit menyebutkan syarat sah perkawinan dan pencatatan sebagai ketertiban administrasi. Kajian ini adalah kajian hukum normatif yang bersifat deskriptif analisis dengan menggunakan teknik analisis secara kualitatif terhadap bahan-bahan hukum primer dan bahan-bahan hukum sekunder. Hasil kajian ini menunjukkan Indonesia terdiri dari beragam kultur kebudayaan, hal ini sangat mempengaruhi sahnya perkawinan, yang mana jika suatu perkawinan sudah dilakukan upacara keagamaan maka perkawinan tersebut sah dan tidak perlu adanya pencatatan. Hal tersebut benar adanya untuk perkawinan yang telah dilakukan secara agama dianggap sah karena agama yang menjadi tolak ukur sahnya atau tidaknya perkawinan tersebut. Akan tetapi Indonesia merupakan negara hukum maka untuk setiap perbuatan haruslah sesuai dengan peraturan dan Undang-Undang yang berlaku, perkawinan setelah dilaksanakan menurut agamanya maka dicatatkan pada KUA/Catatan Sipil setempat.
\end{abstract}

Kata Kunci: pencatatan perkawinan, negara bukum,

\section{A. Pendahuluan}

Di dalam Undang-Undang Dasar tahun 1945 (UUD 1945) sebelum amandemen, dalam pasal 1 ayat (3) dinyatakan bahwa Indonesia adalah negara berdasarkan hukum (rechtstaat). Setelah amandemen ke IV UUD Tahun 1945, kata rechstaat pada pasal 1 ayat (3) UUD Tahun 1945 telah diganti menjadi Indonesia adalah negara hukum. Hal ini dikarenakan Indonesia sebagai negara hukum tidak mengadopsi penuh prinsip-prinsip hukum rechtstaat. Indonesia dalam praktik ketatanegaraan juga menggunakan prinsip hukum yang terdapat dalam negara hukum rule of law serta sistem negara hukum Islam.

Negara hukum Pancasila memiliki merupakan konsep negara hukum yaitu didasarkan pada tiga pilar pengakuan dan perlindungan hak asasi manusia, peradilan yang bebas dan tidak memihak, dan asas legalitas dalam arti formal maupun material, dan di lain 
pihak, diwarnai oleh aspirasi-aspirasi keIndonesiaan yaitu lima nilai fundamental dari Pancasila yang dirumuskan secara materiil didasarkan pada cara pandang bangsa Indonesia dalam bernegara yang bersifat integralistik khas Indonesia, dan secara formal yuridis dengan memperhatikan ketentuan dalam UUD 1945 dengan membandingkan dengan konsep negara hukum liberal yaitu rechttstaat dan rule of law. ${ }^{1}$

Menurut Mahfud $\mathrm{MD}^{2}$, Indonesia menganut sistem negara hukum prismatik, yaitu negara hukum yang hanya mengambil sisi tertentu dari negara hukum lain dan mengkomparasikannya dalam satu sistem hukum. Prinsip negara hukum prismatik inilah yang menjadi dasar negara hukum Pancasila. Pilihan politik Indonesia memilih negara hukum pancasila untuk menjadi suatu sistem hukum tentunya mempunyai suatu pertimbangan yang mendalam, yaitu; a). Kondisi sosiologis Negara Indonesia yang tentunya berbeda dengan negaranegara hukum lain, baik dengan negaranegara yang menganut sistem hukum, rechtstaat, rule of law, Islam, maupun negara hukum otoriter. b) Pluralisme masyarakat Indonesia yang terdiri dari bermacam-macam agama, dan suku bangsa.

Meskipun hukum di Indonesia tidak murni menganut sistem hukum Islam, tetapi hukum di Indonesia telah memberikan ruang bagi umat Islam di Indonesia seperti berlakunya undangundang perkawinan, undang-undang tentang wakaf, dan ketentuan-

1 A. Mukthie Fadjar, Tipe Negara Hukum, (Malang: Bayu Media, 2005), h. 8688

2 Moh. Mahfud MD, , Perdebatan Hukum Tata Negara Pascaamandemen Konstitusi, (Jakarta: Rajawali Pers,2013), h. 6 ketentuan hukum Islam yang telah teratifikasi dalam hukum nasional Indonesia. Peraturan-peraturan hukum di Indonesia pun telah menjamin dan memberikan hak keleluasaan bagi umat Islam di Indonesia.

Indonesia adalah negara berdasarkan hukum (rechtstaat) ${ }^{3}$, maka seluruh aspek kehidupan masyarakat haruslah diatur berdasarkan hukum salah satunya adalah mengenai perkawinan. Perkawinan merupakan persoalan yang penting bagi kehidupan manusia, karena disamping perkawinan sebagai sarana untuk membentuk keluarga, perkawinan juga merupakan hak asasi manusia untuk memenuhi kebutuhan seksualnya. ${ }^{4}$ Perkawinan pada awalnya hanya hubungan pria dengan wanita, tetapi pada akhirnya akan menimbulkan hak di satu pihak dan kewajiban di pihak lain.

Dalam pasal 1 ayat (1) UU No. 1 Tahun 1974, bahwa perkawinan adalah ikatan lahir batin antara seorang pria dengan seorang wanita sebagai suami isteri dengan tujuan untuk membentuk keluarga yang bahagia dan kekal berdasarkan Ketuhanan Yang Maha Esa. ${ }^{5}$ Di dalam agama Islam, perkawinan merupakan salah satu perikatan yang telah disyari'atkan. Hal ini dilakukan untuk menjalankan perintah Allah agar manusia tidak melakukan perzinaan, perkawinan dalam hukum Islam adalah akad yang sangat kuat atau miisaqan galizan untuk

3 C.T.S Kansil, Pengantar Ilmu Hukum dan Tata Hukum di Indonesia, cet. $\mathrm{Ke}-7$ (Jakarta: Balai Pustaka, 1989), h. 41

4 Wasman dan Wardah Nuroniyah, Hukum Perkawinan Islam d Indonesia, Perbandingan Fiqih Dan Hukum Positif, (Yogyakarta: Teras, 2011), h. 29

5 Undang-undang No.1 Tahun 1974 tentang Perkawinan, Pasal 1 
mentaati perintah Allah dan melaksanakannya merupakan ibadah. ${ }^{6}$

Beberapa firman Allah yang berhubungan dengan disyari'atkannya perkawinan antara lain:

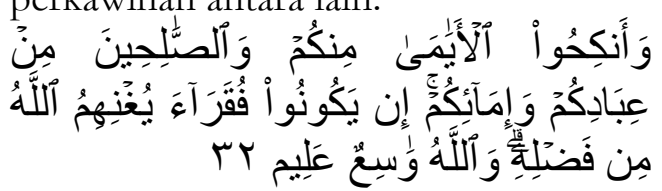

"Dan nikabkanlah orang-orang yang sendirian di antara kamu, dan orang-orang yang layak (bernikah) dari hamba-hamba sahayamu yang perempuan. Jika mereka miskin, Allah akan memampukan mereka dengan kurnia-Nya. Dan Allah Maha luas pemberian-Nya lagi Maha Mengetabui." (Q.S.An-Nur: 32)?.

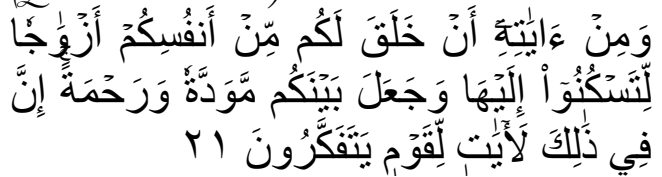

"Dan di antara tanda-tanda kekuasaanNya ialah Dia menciptakan untukmu isteriisteri dari jenismu sendiri, supaya kamu cenderung dan merasa tenteram kepadanya, dan dijadikan-Nya diantaramu rasa kasib dan sayang. Sesunggubnya pada yang demikian itu benar-benar terdapat tandatanda bagi kaum yang berfikir."(Q.S. ArRum : 21)

Dari ayat-ayat di atas menjelaskan bahwa tujuan perkawinan adalah membentuk keluarga yang sakinah, mawaddah dan rahmah. Selain itu perkawinan merupakan cara pemenuhan naluriah kemanusiaan, dan sebagai pelaksanaan ibadah serta untuk mendapatkan keturunan sebagai wujud kasih sayang dan penerus hidup dan kehidupan setiap manusia. Kasih sayang yang dimaksud adalah kasih sayang yang sejati dan abadi, dari usia muda sampai ke usia tuanya.

\footnotetext{
${ }^{6}$ Lihat dalam KHI Bab II, Pasal 2

${ }^{7}$ Q.S.An-Nur : 32

${ }^{8}$ Q.S. Ar-Rum : 21
}

Undang-Undang No. 1 Tahun 1974 tentang Perkawinan Pasal 1 menyatakan bahwa perkawinan sebagai ikatan lahir batin antara seorang pria dengan seorang wanita sebagai suami istri dengan tujuan membentuk keluarga rumah tangga yang bahagia dan kekal berdasarkan Ketuhanan Yang Maha Esa. Berdasarkan hal tersebut, perkawinan pada hakikatnya adalah kebahagiaan. Kebahagiaan berarti kemaslahatan atau keadilan bagi seluruh anggota keluarga yang muncul akibat hubungan perkawinan tersebut.

Salah satu hal yang menjadi penting dalam perkawinan adalah keabsahan perkawinan. Di dalam Undang-Undang No. 1 Tahun 1974 tentang Perkawinan Pasal 2 ayat (1) dinyatakan bahwa: "Perkawinan adalah sah, apabila dilakukan menurut hukum masingmasing agamanya dan kepercayaannya itu", ayat selanjutnya menyatakan bahwa "Tiap-tiap perkawinan dicatat menurut peraturan perundangundangan yang berlaku". Secara umum ayat-ayat tersebut tidak bermasalah karena mengatur dua hal yang berbeda, pertama mengatur tentang keabsahan perkawinan, kedua mengatur tentang pencatatan perkawinan. Namun kemudian ada ketentuan-ketentuan tentang pencatatan perkawinan yang lebih tegas yang prinsipnya menyatakan keharusan melakukan pencatatan perkawinan, perkawinan harus dilangsungkan di hadapan dan di bawah pengawasan Pegawai Pencatat Nikah dan jika melanggarnya dipidana serta perkawinan yang tidak dicatatkan tidak mempunyai kekuatan hukum tetap. ${ }^{9}$

9 Peraturan Pemerintah Republik Indonesia Nomor 9 Tahun 1975 Tentang Pelaksanaan Undang- Undang

Nomor 1 Tahun $1974 \quad$ Tentang Perkawinan, pada Pasal 3 ayat (1), Pasal 10 
Banyaknya interpretasi hukum secara jelas telah ditampilkan dalam teks undang-undang, dalam hal ini mengenai persoalan pencatatan perkawinan baik di dalam UndangUndang No. 1 Tahun 1974 tentang Perkawinan dalam pasal 2 ayat (1) dan (2) maupun dalam KHI pasal 4, 5, 6 dan 7 yang secara eksplisit menyebutkan syarat sah perkawinan dan pencatatan sebagai ketertiban administrasi.

Tidak adanya alat bukti berupa pencatatan suatu perkawinan akan berdampak pada tidak terlaksananya hukum Islam dengan baik, khususnya hukum yang berhubungan abwal al syakbshiyyah seperti dalam aspek nafkah isteri, nafkah anak, pendidikan anak, waris mewarisi, hukum tentang halangan perkawinan (mahram), dan sebagainya. Tanpa adanya alat bukti yang jelas mungkin saja terjadi perkawinan antara seorang perempuan dengan saudara laki-lakinya, tidak dapatnya ditentukan dengan cepat siapa ahli waris seseorang, siapa yang bertanggung jawab terhadap nafkah dan pendidikan anak, sehingga tidak adanya kepastian hukum. Kajian ini bertujuan untuk menganalisis dan memahami pencatatan perkawinan dalam konsep negara hukum Pancasila. Kajian ini menggunakan pendekatan konsep (conceptual approach) dan pendekatan perundang-perundangan (statute approach).

\section{B. Pembahasan}

Pencatatan perkawinan pada prinsipnya merupakan hak dasar atau bajjiyah dalam keluarga. Pencatatan perkawinan tidak diatur di dalam nash, baik al-Qur`an maupun sunnah. Dalam

ayat (3) dan Pasal 45 ayat (1) huruf (a) dan Kompilasi Hukum Islam, pada Pasal 5 dan 6. figh tidak ada pengaturan pencatatan perkawinan. ${ }^{10}$ Walaupun al-Qur'an telah menganjurkan pencatatan dalam transaksi muamalah dalam keadaan tertentu. Seperti dalam firman Allah, SWT:
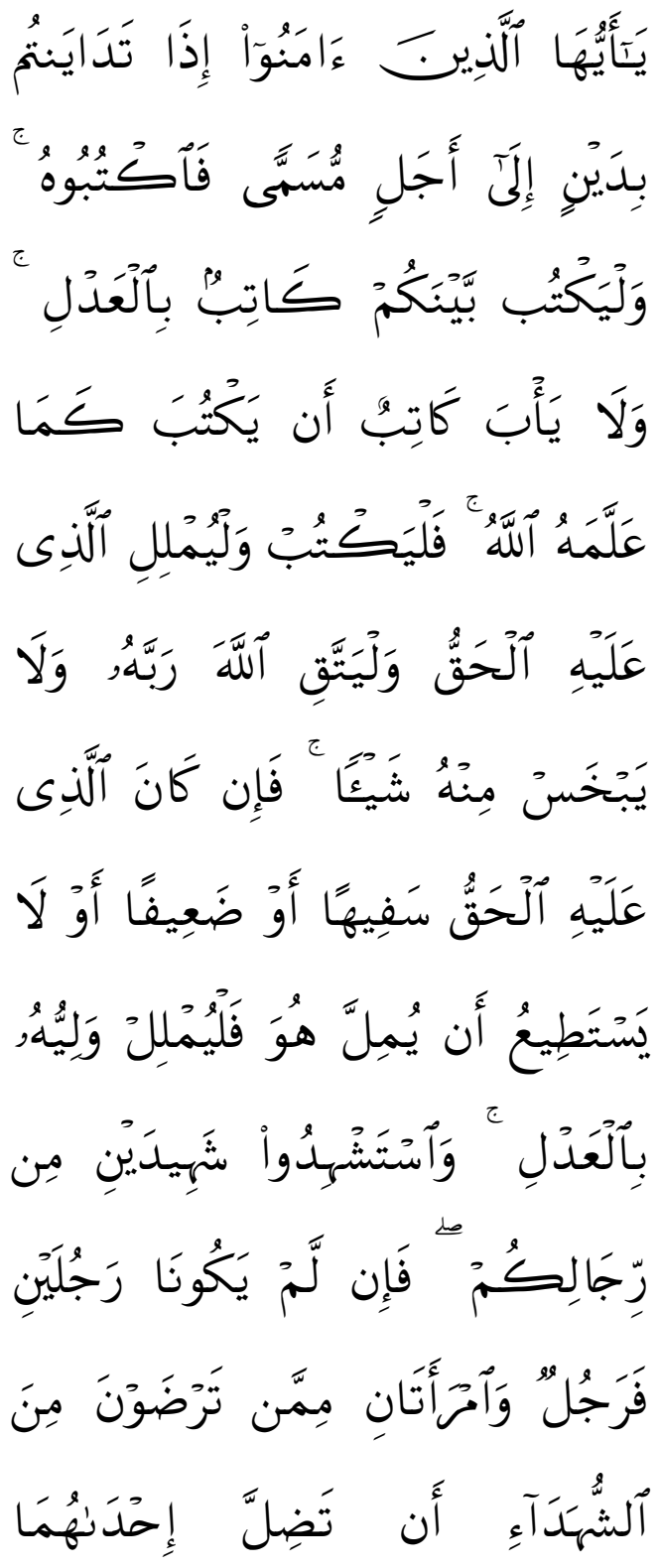

${ }^{10}$ Khoiruddin Nasution, Status Wanita di Asia Tenggara: Studi Terbadap Perundangundangan Perkawinan Muslim Kontemporer di Indonesia dan Malaysia (Jakarta: NIS, 2002), h. 139 


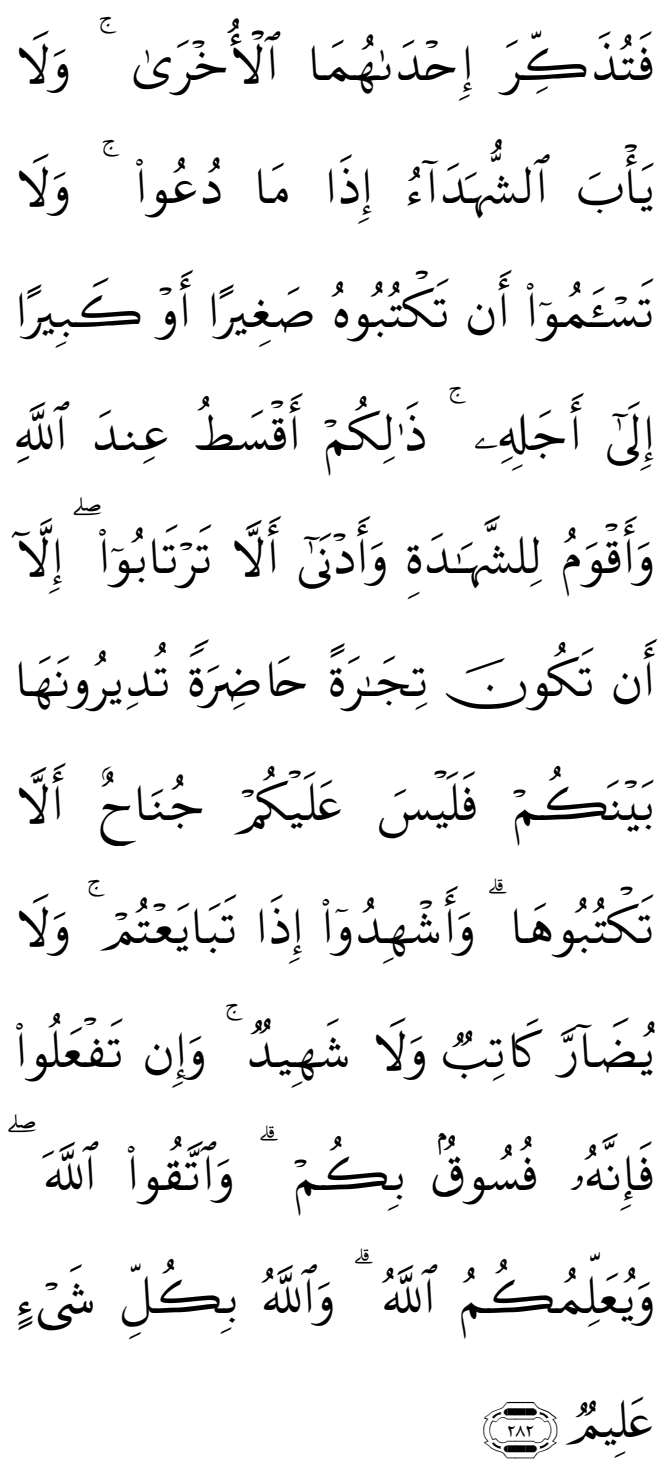

Hai orang-orang yang beriman, apabila kamu bermu'amalah[179] tidak secara tunai untuk waktu yang ditentukan, hendaklah kamu menuliskannya. dan hendaklah seorang penulis di antara kamu menuliskannya dengan benar. dan janganlah penulis enggan menuliskannya sebagaimana Allah mengajarkannya, meka hendaklah ia menulis, dan hendaklah orang yang berhutang itu mengimlakkan (apa yang akan ditulis itu), dan hendaklah ia bertakwa kepada Allah Tuhannya, dan janganlah ia mengurangi sedikitpun daripada hutangnya. jika yang berhutang itu orang yang lemah akalnya atau lemah (keadaannya) atau dia sendiri tidak mampu mengimlakkan, Maka hendaklah walinya mengimlakkan dengan jujur. dan persaksikanlah dengan dua orang saksi dari orangorang lelaki (di antaramu). jika tak ada dua oang lelaki, Maka (boleh) seorang lelaki dan dua orang perempuan dari saksi-saksi yang kamu ridhai, supaya jika seorang lupa Maka yang seorang mengingatkannya. janganlah saksi-saksi itu enggan (memberi keterangan) apabila mereka dipanggil; dan janganlah kamu jemu menulis hutang itu, baik kecil maupun besar sampai batas waktu membayarnya. yang demikian itu, lebih adil di sisi Allah dan lebih menguatkan persaksian dan lebih dekat kepada tidak (menimbulkan) keraguanmu. (Tulislah mu'amalahmu itu), kecuali jika mu'amalah itu perdagangan tunai yang kamu jalankan di antara kamu, Maka tidak ada dosa bagi kamu, (jika) kamu tidak menulisnya. dan persaksikanlah apabila kamu berjual beli; dan janganlah penulis dan saksi saling sulit menyulitkan. jika kamu lakukan (yang demikian), Maka Sesungguhnya hal itu adalah suatu kefasikan pada dirimu. dan bertakwalah kepada Allah; Allah mengajarmu; dan Allah Maha mengetahui segala sesuatu. "11 (QS. AlBaqarah : 282 $)^{12}$

Pencatatan perkawinan merupakan implementasi rumusan dari konsep Maqasid al-Syariab dalam pencatatan perkawinan, yaitu perlindungan terhadap keturunan (bifz, an-Nasl) dan perlindungan terhadap harta (bifz, alMal). Hifz an-Nasl, yaitu sebuah perlindungan terhadap keturunan demi kelestarian manusia agar tetap hidup

\footnotetext{
11 Departemen Agama RI, Bahan Penyuluban Hukum, Jakarta: Departemen $\begin{array}{ll}\text { Agama RI, 2000), } & \text { h. } 70\end{array}$ 12 QS. Al-Baqarah : 282
} 
dan berkembang sehat lahir maupun batin, baik budi pekerti dan agamanya.

Dengan perlindungan ini maka nasab seseorang akan dengan mudah diketahui. Hifz al-Mal, yaitu sebuah perlindungan harta sehingga dapat meningkatkan kekayaan secara proporsional dengan melalui cara-cara yang halal, bukan dengan hal-hal yang curang. Dengan adanya perlindungan ini, maka seseorang akan dapat mempertahankan apa saja yang menjadi hak miliknya seperti dalam hal waris dan wasiat. Banyak hal yang dapat dirugikan bila suatu perkawinan tidak dicatatkan, salah satunya jika suatu saat mereka berpisah maka si wanita tidak mendapatkan hak-haknya serta kepada anaknya kelak.

Konsep Negara hukum Pancasila merupakan konsep Negara hukum yang prismatik ${ }^{13}$, artinya, konsep Negara hukum tersebut mengintegerasi unsur-unsur baik yang dari hal-hal yang terkandung di berbagai sistem hukum. Dengan prinsip Pancasila yang bersifat prismatik, maka diharapkan tujuan Negara sebagaimana yang tercantum dalam Pembukaan Undang-Undang Dasar Negara Republik Indonesia Tahun 1945 alinea keempat, yaitu melindungi segenap bangsa Indonesia, dan seluruh tumpah darah Indonesia, dan untuk memajukan kesejahteraan umum, mencerdaskan kehidupan bangsa, dan ikut melaksanakan ketertiban dunia yang berdasarkan kemerdekaan, perdamaian abadi, dan keadilan sosial dapat tercapai. Hambatan-hambatan dalam pembangunan konsep Negara hukum Pancasila di Indonesia, baik hambatan

\footnotetext{
13 Fred W. Riggs, Administrasi Negaranegara Berkembang: Teori Masyarakat Prismatis, terj. Yasogama (Jakarta: PT Raja Grafindo,1988), h. 31
}

dari luar maupun hambatan dari dalam harus ditekan.

Setiap warga Negara Indonesia terlibat dalam semua lapangan kehidupan tersebut, dan karena itu wajib berpegang teguh kepada Pancasila sebagai satu-satunya asas. Untuk itu, Pancasila harus dimasyarakatkan agar menjadi milik masyarakat, harus dibudayakan agar mendarah daging dalam diri manusia Indonesia, menjadi pedoman baginya dalam mengaktualisasi dirinya dalam kehidupan bermasyarakat, berbangsa, dan bernegara. ${ }^{14}$

Indonesia terdiri dari beragam kultur kebudayaan, hal ini sangat mempengaruhi sahnya perkawinan, yang mana jika suatu perkawinan sudah dilakukan upacara keagamaan maka perkawinan tersebut sah dan tidak perlu adanya pencatatan. Hal tersebut benar adanya untuk perkawinan yang telah dilakukan secara agama dianggap sah karena agama yang menjadi tolak ukur sahnya atau tidaknya perkawinan tersebut. Akan tetapi Indonesia merupakan negara hukum maka untuk setiap perbuatan haruslah sesuai dengan peraturan dan Undang-Undang yang berlaku, perkawinan setelah dilaksanakan menurut agamanya maka dicatatkan pada KUA/Catatan Sipil setempat.

\section{Kesimpulan}

Berdasarkan uraian di atas maka dapat disimpulkan yaitu Pencatatan perkawinan menjadi keharusan dalam konsep negara hukum Pancasila, dan banyak akibat yang ditimbukan jika perkawinan tidak dicatatakan.

14 R.M.S. Gultom, dkk, Ideologi, Konstitusi, dan Pembangunan Nasional Indonesia, (Semarang: Satya Wacana Lestari Jaya: 1997), h. 22 


\section{Daftar Pustaka}

Departemen Agama RI, Bahan Penyuluban Hukum, Jakarta: Departemen Agama RI, 2000

Fadjar, Mukthie, Tipe Negara Hukum, Malang: Bayu Media, 2005

Gultom, R.M.S., dkk, Ideologi, Konstitusi, dan Pembangunan Nasional
Indonesia, Semarang: Satya
Wacana Lestari Jaya: 1997

Kansil, C.T.S, Pengantar Imu Hukum dan Tata Hukum di Indonesia, cet. Ke-7 Jakarta: Balai Pustaka, 1989

Khoiruddin Nasution, Status Wanita di Asia Tenggara: Studi Terhadap Perundang-undangan Perkawinan Muslim Kontemporer di Indonesia dan Malaysia, Jakarta: NIS, 2002

Mahfud MD, Moh., Perdebatan Hukum Tata Negara Pasca amandemen Konstitusi, Jakarta: Rajawali Pers,2013

Riggs, Fred W., Administrasi Negaranegara Berkembang: Teori Masyarakat Prismatis, terj. Yasogama Jakarta: PT Raja Grafindo,1988

Wasman, Wardah Nuroniyah, Hukum Perkawinan Islam di Indonesia, Perbandingan Fiqib Dan Hukum Positif,Yogyakarta: Teras, 2011 